
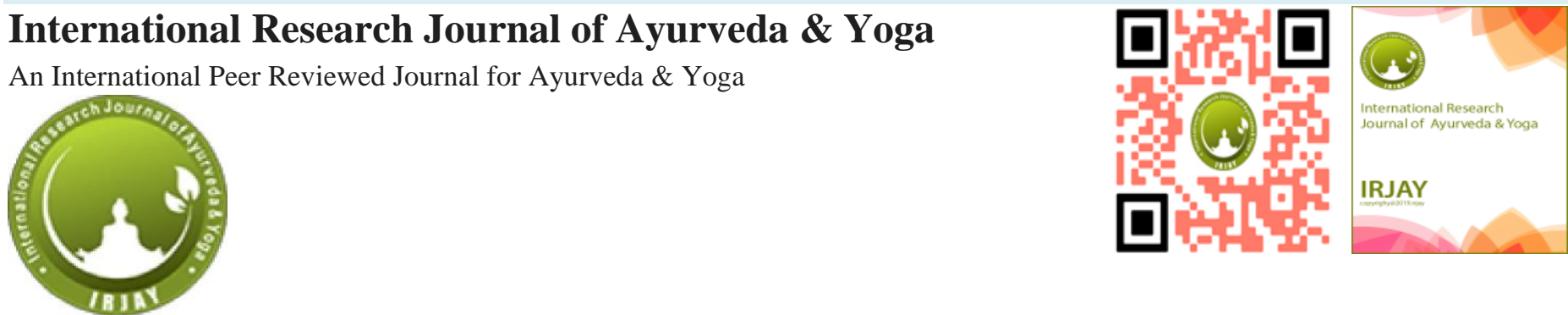

\title{
Clinical Efficacy Of Bhudhatryadi Yoga In The Management Of Prameha Roga W.S.R. To Diabetes Mellitus \\ Dr. Anil Badhoria ${ }^{1}$ Dr. Ramesh Kaundal ${ }^{2}$
}

ICV-70.44- ISRA-1.31

VOLUME 4 ISSUE 3 March 2021

1. Reader, Govt. Ayurvedic Medical College J\&K, UT.

2. Lecturer Dept. Of Shalya tantra Govt. Ayurvedic College Patiala Punjab.

Corresponding Author : Dr. Anil Badhoria, Reader Govt. Ayurvedic Medical College J\&K UT,

Email id: anildrbadhoria@gmail.com

\section{ABSTRACT: -}

Background -In spite of all sorts of advancements of science, in this world, man is not able to sail himself in the boat of happy \& healthy life. Unnatural ways of life style, increased population and moreover world of machines has created unlimited desires in human mind on the one hand, while on the other hand, it has originated anxiety, anger, hostility \& grief directly or indirectly. So many diseases are there which are output of unnatural dietary habits, restless lifestyle and stress, one of such is Diabetes. The syndrome of Diabetes Mellitus is largely covered under the broad heading of Prameha. Prameha is a disease which is revealed by Mutravaha Srotasa [Urinary system].

Aim- To assess the clinical efficacy of Bhudhatryadi Yoga in in the management of Prameha Roga w.s.r. to Diabetes Mellitus

Material and Method-30 Patients were selected randomly from OPD and IPD of Kayachiktisa Deptt. of Jammu Institute of Ayurveda and Research hospital. Selected patients were administered Bhudhatryadi yoga $3 \mathrm{gm}$ bid for a period of 45 days along with life style modifications. Weekly follow up of patients was done, while biochemical investigations were carried out before and after trial.

Result-. Marked Improvement was seen in $16.66 \%$ patients. $40 \%$ of cases presented Moderate Improvement and $36.66 \%$ were categorized as Mildly Improved after the treatment.

Conclusion- Bhudhatryadi yoga has better effects in reducing blood sugar level.

Keywords: Diabetes Mellitus, Bhudhatryadi yoga, Gramya Ahara 


\section{@1) 0 Q $\Theta$}

This work is licensed under a creative attribution -Non-commercial-No derivatives 4.0 International License commons

How to cite this article: -Dr. Anil Badhoria, Dr. Ramesh Kaundal Clinical Efficacy Of Bhudhatryadi Yoga In The Management Of Prameha Roga W.S.R. To Diabetes Mellitus, IRJAY, March: 2021, Vol-4, Issue-3; 17-26; DOI: https://doi.org/10.47223/IRJAY.2021.4326

\section{INTRODUCTION}

Ayurveda is one of the most ancient medical sciences of the world. It conceives and describes the basic and applied aspects of life process, health, disease and its management in terms of its own principles and approaches. ${ }^{1}$ Prameha described in Ayurvedic literature have similarity with Type-2 Non-Insulin Dependent Diabetes Mellitus (NIDDM). ${ }^{2}$ Here the study is focused on Type-2 Diabetic patients only to understand its etiopathogenesis and actual line of treatment from Ayurvedic view point. Diabetes Mellitus (DM) is a chronic disease marked by elevated blood glucose level. ${ }^{3}$ It affects 5-6\% of the global adult population. Type 2 diabetes prevalence is rising at alarming rates worldwide because of increased urbanization, high prevalence of obesity, sedentary lifestyles and stress, among other factors. ${ }^{4} \mathrm{Up}$ to $80 \%$ of type 2 Diabetes is preventable by adopting a healthy diet and increasing physical activity. India has the largest diabetes population in the world with an estimated 41 million people, amounting to $6 \%$ of the adult population. India is the kingdom of Diabetes, having more than 5 crore patients of it. ${ }^{5}$ Diabetes has shifted down a generation as with rapid increase in prevalence of diabetes, the age of susception is decreasing promptly and has touched the thirties which are economically most productive years. The study drug selected for this clinical trial is Bhudhatryadi Yoga stated by Yoga Ratnakar. ${ }^{6}$ The effect of the compound may be synergistic or antagonist depending upon the similar qualities and opposite qualities of the Dravyas respectively. ${ }^{7}$ The final effect of combination of substances having similar properties i.e. Prakratisamasmaveta can be inferred due to similarity of properties of individual exhibits synergistic effects while effect of combination of substances having different properties i.e. Vikrativisamasamveta can't be inferred through knowing properties of individual substances. Our Aim is to study the clinical efficacy of Bhudhatryadi Yoga in Prameha Roga (Diabetes Mellitus)

\section{AIMS AND OBJECTIVE}

To assess the efficacy of Bhudhatryadi yoga in Prameha Roga w.s.r. to Diabetes Mellitus

\section{MATERIAL AND METHOD}

\section{Selection of Case}

- 30 Patients were selected randomly from OPD and IPD of Kayachikitsa Deptt. of Jammu Institute of Ayurveda and Research hospital.

- All the patients were clinically diagnosed cases of Diabetes Mellitus and were properly registered.

- Details of examination and investigations were carefully recorded in the proforma.

\section{Inclusion Criteria}

- Mild to moderate cases of Diabetes Mellitus having fasting blood sugar within range:-

Mild -126 to $140 \mathrm{mg} / \mathrm{dl}$

Moderate -140 to $160 \mathrm{mg} / \mathrm{dl}$

- Patients above the age group of 18 years and below 60 years were selected.

- Patients within $1 \mathrm{yr}$ of diagnosis for diabetes mellitus were selected for the study.

\section{Exclusion Criteria}

- Patients with type 1 D.M. 
- Type 2 D.M. patients who were insulin dependent.

- Patients with F.B.S. more than $160 \mathrm{mg} / \mathrm{dl} \&$ P.P.B.S. more than $220 \mathrm{mg} / \mathrm{dl}$.

- Diabetic patients with severe complications like cardiovascular diseases, Nephropathy, Retinopathy, Diabetic foot etc.

- Patients of Gestational diabetes.

- Diabetes due to endocrinopathy e.g. Cushing's syndrome, Hyperthyroidism, Acromegaly etc.

- Patients with certain genetic syndromes which are sometimes associated with diabetes mellitus e.g. Down's syndrome, Klinefelter's syndrome, Turner's syndrome etc.

- Patients suffering from terminal sickness.

- Patients who don't adopt or follow the instructions regarding life style modifications during the trial period.

\section{Investigations -}

Following investigations were carried out in all the patients.

1. Fasting blood sugar (F.B.S) and Post prandial blood sugar (P.P.B.S.).

2. Routine examination of blood like $\mathrm{Hb} \%$, T.L.C., D.L.C., E.S.R. , C.T, B.T. to exclude any pathology.

3. Routine examination of urine.

- Special investigation were done in few Patient ie.HbA1c

\section{PLAN OF STUDY:}

Patients randomly selected for the study were taken in single group. Research Proforma was filled. In the patients who were taking oral hypoglycemic drugs, blood sugar level at that time was taken as basal level. Study drug was administered. Effect of study drug was observed in relation to basal sugar level and sign and symptoms.

\section{Design:}

It is a single blind clinical study with a pre-test and post-test design. In this study, 30 patients diagnosed of diabetes mellitus of either sex were subjected to clinical study.

\section{Intervention:}

Bhudhatryadi yoga was orally administered in a dose of $3 \mathrm{gm}$ twice daily after meals for 45 days.

Recently diagnosed patients, mild to moderate cases of type 2 Diabetes (NIDDM- Apathya Nimittaja Prameha) were kept on Bhudhatryadi yoga along with controlled diet and physical activity from pathya point of view.

These patients were provided a proper diet chart planned according to our classics.

Duration of study-45days

\section{Criteria for Assessment:}

Assessment of result has been made on the basis of following criteria, after completion of treatment.

1. Sign and symptoms before and after treatment.

2. F.B.S. and P.P.B.S. before and after treatment.

3. Assessment of changes observed in sign and symptoms and biochemical parameter is done on the basis of specific scoring pattern.

4. Depending upon severity, following symptoms score was utilized and assessment of clinical sign and symptoms was done.

\section{OBSERVATIONS}

Total 30 patients were registered for the present study.

Table 1: Age wise distribution of patients:

\begin{tabular}{|l|l|l|}
\hline Age(Years) & No. of patients & Percentage \\
\hline $0-10$ & 0 & 0 \\
\hline $11-20$ & 0 & 0 \\
\hline $21-30$ & 0 & 0 \\
\hline $31-40$ & 3 & 10 \\
\hline $41-50$ & 15 & 50 \\
\hline $51-60$ & 12 & 40 \\
\hline
\end{tabular}


Patients selected for study were in the range of 3160 yrs of age. Maximum no. of patients i.e. $60 \%$ belonged to the age group 41-50 yrs. $30 \%$ of patients belonged to 51-60 yrs age group and 10\% of patients were in between 31-40 yrs of age.

Table 2: Ahara wise distribution of patients:

\begin{tabular}{|l|l|l|}
\hline Ahara & No. of patients & Percentage \\
\hline Veg. & 17 & 56.67 \\
\hline Non-veg & 0 & 00.00 \\
\hline Mixed & 13 & 43.33 \\
\hline
\end{tabular}

Out of 30 patients, $56.67 \%$ of patients were purely Vegetarian, $43.33 \%$ of patients were taking Mixed

(Veg. \& Non-veg.) diet.

Table 3: Addiction wise distribution of patients:

\begin{tabular}{|l|l|l|}
\hline Addiction & No. of patients & Percentage \\
\hline Tea & 15 & 50 \\
\hline Coffee & 0 & 00.00 \\
\hline Tobacco & 4 & 13.33 \\
\hline Smoking & 5 & 16.67 \\
\hline Alcohol & 4 & 13.33 \\
\hline Soft drinks & 0 & 00.00 \\
\hline No addiction & 2 & 6.67 \\
\hline
\end{tabular}

Maximum no. of patients $(50 \%)$ were found habituated to Tea, $16.66 \%$ were addicted to Alcohol and $6.66 \%$ were not having any kind of Smoking, $13.33 \%$ were addicted to Tobacco and addiction.

Table 4: Sleeping pattern wise distribution of patients:

\begin{tabular}{|l|l|l|}
\hline Nidra (sleep) & No. of patients & Percentage \\
\hline Samyaka (proper) & 20 & 66.67 \\
\hline Asamyaka (improper) & 10 & 33.33 \\
\hline
\end{tabular}

\section{Diwaswapa (day sleep)}

\begin{tabular}{|l|l|l|}
\hline $\begin{array}{l}\text { No diwaswapa (day } \\
\text { sleep) }\end{array}$ & 10 & 33.33 \\
\hline Regular & 15 & 50 \\
\hline Irregular & 5 & 16.67 \\
\hline
\end{tabular}


Ratrijagarana (awake during night)

Research Article.

\begin{tabular}{|l|l|l|}
\hline No Ratrijagarana & 23 & 76.67 \\
\hline Regular & 1 & 3.33 \\
\hline Irregular & 6 & 20 \\
\hline
\end{tabular}

Data shows that $33.33 \%$ of the patients were having Asamyaka Nidra (improper sleep) and $66.67 \%$ were having Samyaka Nidra (proper sleep). $50 \%$ of the patients were having Regular Diwaswapa, $16.66 \%$ were having Irregular Diwaswapa (day sleep) and
$33.33 \%$ of them were not habituated to Diwaswapa (day sleep). Max. no.of patients (76.67\%) were not habituated to Ratrijagarana, $3.33 \%$ were having Regular Ratrijagarana and $20 \%$ were doing Irregular Ratrijagarana.

Table 4: Distribution of patients according to Nature of work:

\begin{tabular}{|l|l|l|}
\hline Nature of work & No. of patients & Percentage \\
\hline Sedentary & 24 & 80 \\
\hline Active & 4 & 13.33 \\
\hline Heavy & 2 & 6.67 \\
\hline
\end{tabular}

Data reveals that out of 30 patients, $80 \%$ of the patients were having Sedentary nature of work,
$13.3 \%$ were performing Active work and 6.66\% were having Heavy physical work load.

Table 5: Distribution of patients according to Bowel-habit:

\begin{tabular}{|l|l|l|}
\hline Bowel-habit & No. of patients & Percentage \\
\hline Regular & 10 & 33.33 \\
\hline Irregular & 5 & 16.67 \\
\hline Constipated & 15 & 50 \\
\hline
\end{tabular}

Table 5 shows that, $50 \%$ of the patients were having having Regular bowel-habit and 16.67\% had Constipated bowel habit, $33.33 \%$ of them were Irregular bowel-habit.

Table 6: Prakriti wise (Constitution) distribution of patients:

\begin{tabular}{|l|l|l|}
\hline Prakriti (Sharira) & No. of patients & Percentage \\
\hline Vata pitta & 4 & 13.33 \\
\hline Vata kapha & 10 & 33.33 \\
\hline Kapha pitta & 16 & 53.34 \\
\hline
\end{tabular}

Table 6 indicates that, $53.34 \%$ of patients were having Kapha-pitta dominance in their Prakriti,
33.33\% were having Vata-kaphaja Prakriti and 13.33\% had Vata-pittaja Prakriti. 
Table 7: Aharashakti wise distribution of patients:

\begin{tabular}{|l|l|l|}
\hline Aharashakti & No. of patients & Percentage \\
\hline \multicolumn{2}{|c|}{ Abhyavaharanashakti } \\
\hline $\begin{array}{l}\text { Pravara (finest) } \\
\text { Madhyama }\end{array}$ & 8 & 26.67 \\
\hline Avedium) & 20 & 66.67 \\
\hline \multicolumn{2}{|c|}{ Jaranashakti $($ weak) } & 6.66 \\
\hline $\begin{array}{l}\text { Pravara(finest) } \\
\text { (madhyama }\end{array}$ & 81 & 26.67 \\
\hline Avara (weak) & 1 & 70 \\
\hline
\end{tabular}

Table 7 gives information of Aharashakti of 30 patients which can be assessed with the help of Abhyavaharanashakti and Jaranashakti. Majority of patients i.e. $66.67 \%$ were having Madhyama
Abhyavaharanashakti, $26.67 \%$ had Pravara and $6.66 \%$ had Avara Abhyavaharana-shakti. $70 \%$ of the patients had Madhyama Jaranashakti, 26.67\% had Pravara and $3.33 \%$ had Avara Jaranashakti

Table 8: Signs and Symptoms observed in patients:

\begin{tabular}{|l|l|l|}
\hline Main Signs and Symptoms & No. of patients & Percentage \\
\hline Prabhuta mutrata (Polyurea) & 30 & 100 \\
\hline Avila mutrata (Turbid urine) & 10 & 33.33 \\
\hline $\begin{array}{l}\text { Trishnadhikya \& Gal-talu } \\
\text { shosha (excessive thirst and } \\
\text { drynesss of throat) }\end{array}$ & 30 & 100 \\
\hline
\end{tabular}

Table 8 indicates observations of Main Sign and Symptoms specific to Prameha. Data reveals that Prabhuta mutrata and Avila mutrata were found in
$100 \%$ and $33.33 \%$ of patients respectively. Trishnadhikya and Gal-talu shosha were found in $100 \%$ of patients.

\section{RESULT}

\section{EFFICACY OF TREATMENT}

- Main Signs and Symptoms of Prameha.

Table 10: Effect on Prabhuta Mutrata (Polyurea):

\begin{tabular}{|l|l|l|l|l|l|l|l|}
\hline & \multicolumn{2}{|l|}{$\begin{array}{l}\text { Mean } \\
\text { Score }\end{array}$} & \% Relief & $\begin{array}{l}\text { S.D. } \\
( \pm)\end{array}$ & $\begin{array}{l}\text { S.E. } \\
( \pm)\end{array}$ & t & P \\
\cline { 2 - 7 } & B.T. & A.T. & & & & & \\
\hline N=30 & 1.86 & $\mathbf{0 . 5 3}$ & 71.50 & 0.479 & 0.087 & 15.23 & $<0.001$ \\
\hline
\end{tabular}


The table 21 shows that mean initial score for Prabhuta mutrata was 1.86, which reduced to 0.53 , showing $71.50 \%$ improvement. Statistical analysis shows that the improvement was highly significant at $\mathrm{P}<0.001$.

Table 11: Effect on Avila Mutrata (Turbid urine):

\begin{tabular}{|l|l|l|l|l|l|l|l|}
\hline & \multicolumn{2}{|l|}{$\begin{array}{l}\text { Mean } \\
\text { Score }\end{array}$} & \% Relief & $\begin{array}{l}\text { S.D. } \\
( \pm)\end{array}$ & $\begin{array}{l}\text { S.E. } \\
( \pm)\end{array}$ & t & P \\
\cline { 2 - 7 } & B.T. & A.T. & & & & & \\
\hline N=10 & 2.20 & 1.70 & 22.72 & 0.71 & 0.22 & 2.236 & $>0.05$ \\
\hline
\end{tabular}

In this group, mean score before starting treatment was 2.20 which reduced to 1.70 with $22.72 \%$ relief and gives calculated $\mathrm{t}$ value 2.23 which is insignificant at $\mathrm{p}>0.05$

Table 12: Effect on Trishnadhikya \& Gala-talu-shosha

\begin{tabular}{|l|l|l|l|l|l|l|l|}
\hline & $\begin{array}{l}\text { Mean } \\
\text { Score }\end{array}$ & \% Relief & $\begin{array}{l}\text { S.D. } \\
( \pm)\end{array}$ & $\begin{array}{l}\text { S.E. } \\
( \pm)\end{array}$ & t & P \\
\cline { 2 - 7 } & B.T. & A.T. & & & & & \\
\hline N=30 & $\mathbf{2 . 2 0}$ & $\mathbf{0 . 9 3}$ & $\mathbf{5 7 . 7 2}$ & $\mathbf{0 . 4 5}$ & $\mathbf{0 . 0 8}$ & $\mathbf{1 5 . 4 2}$ & $<\mathbf{0 . 0 0 1}$ \\
\hline
\end{tabular}

Table 12 shows mean score before starting treatment was 2.20 which reduced to 0.93 with relief of $57.72 \%$ and calculated ' $t$ ' value was 15.42 which was found highly significant at $\mathrm{P}<0.001$.

Table 13: Effect on F.B.S. :

\begin{tabular}{|l|l|l|l|l|l|l|l|}
\hline & \multicolumn{2}{|l|}{ Mean Score } & \% Relief & $\begin{array}{l}\text { S.D. } \\
( \pm)\end{array}$ & $\begin{array}{l}\text { S.E. } \\
( \pm)\end{array}$ & t & P \\
\cline { 2 - 6 } & B.T. & A.T. & & & & & \\
\hline N=30 & 147.96 & 109.33 & 26.11 & 4.73 & 0.86 & 44.66 & $<0.001$ \\
\hline
\end{tabular}

Mean score before starting treatment was 147.96 which reduced to 109.33 with relief of $26.11 \%$ and calculated ' $t$ ' value was 44.66 which was found highly significant at $\mathrm{P}<0.001$.

Table 14: Effect on P.P.B.S. :

\begin{tabular}{|l|l|l|l|l|l|l|l|}
\hline & \multicolumn{2}{|l|}{ Mean Score } & \% Relief & $\begin{array}{l}\text { S.D. } \\
( \pm)\end{array}$ & $\begin{array}{l}\text { S.E. } \\
( \pm)\end{array}$ & t & P \\
& B.T. & A.T. & & & & & \\
\cline { 2 - 8 } N=30 & 195.23 & 154.40 & 20.91 & 2.26 & 0.41 & 98.95 & $<0.001$ \\
\hline
\end{tabular}

Mean score before starting treatment was 195.23 which reduced to 154.40 with relief of $20.91 \%$ and calculated ' $t$ ' value was 98.95 which was found highly significant at $\mathrm{P}<0.001$. 
Table 15 OVERALL EFFECT OF THERAPY

- Improvement In Signs and Symptoms:

\begin{tabular}{|l|l|l|}
\hline RESULTS & Patients & Percentage \\
\hline Controlled & 2 & 6.66 \\
\hline Marked Improvement & 5 & 16.66 \\
\hline Moderate Improvement & 12 & 40 \\
\hline Mild Improvement & 11 & 36.66 \\
\hline Unchanged & 0 & 0.00 \\
\hline
\end{tabular}

2 patients $(6.66 \%)$ assessed as controlled and 5 patients (16.66\%) as Markedly Improved. Moderate Improvement was seen in 12 patients (40\%) whereas Mild Improvement was observed in 11 patients (36.66\%). All patients responded to treatment to some extent and no patient assessed as unchanged

\section{Improvement In Blood Sugar Level}

\begin{tabular}{|l|l|l|l|l|}
\hline \multirow{2}{*}{ RESULTS } & F.B.S. & P.P.B.S. \\
\cline { 2 - 5 } & Patients & Percentage & Patients & Percentage \\
\hline Controlled & & & & \\
\hline Marked Improvement & 10 & 23.33 & 3 & 10 \\
\hline Moderate Improvement & 9 & 33.34 & 6 & 20 \\
\hline Mild Improvement & 4 & 30 & 9 & 30 \\
\hline Unchanged & 0 & 13.33 & 10 & 33.33 \\
\hline
\end{tabular}

Control in F.B.S. was achieved by 7 patients (23.33\%) and that of in P.P.B.S. by 3 patients (10\%). Marked Improvement in F.B.S. was observed in 10 patients (33.34\%) while 6 patients (20\%) for P.P.B.S. was categorized under this grade. Moderate Improvement in F.B.S. and in P.P.B.S. was observed

\section{DISCUSSION}

Prameha (Diabetes Mellitus) has been mentioned as Aanushangi Vyadhi (hereditary disease) by Maharishi Charaka.Chakrapani explained the term Aanushangi as 'Punarbhavi', means a disease that presents itself again and again. ${ }^{8}$ The rising burden of Type 2 diabetes and other non-communicable diseases which has occurred with modernization can be understood in the context of 'epidemiological in 9 patients (30\%). Mild improvement in F.B.S. and in P.P.B.S. was observed in 4 patients $(13.33 \%)$ and 10 patients $(6.67 \%)$ respectively. P.P.B.S. of 2 patients $(6.67 \%)$ remained unchanged.

transition'9. Rapid socio-economic development and coca colonization have resulted in a life style transition from traditional to modern. ${ }^{10}$ In virtually all populations, higher fat diets and decreased physical activity have accompanied the benefits of modernization. Exercise has been engineered out of our daily lives, both in the work place \& leisure. These lifestyle changes when combined with increasing longevity form the basis of the dynamic Type 2 diabetes epidemic that we are witnessing 
today. ${ }^{11}$ The western lifestyle must have unmasked the effects of pre-existing genes because the consistent result has been diabetes within a few decades. The present study was completed to evaluate the efficacy of an Bhudhatryadi Yoga in Prameha Roga (diabetes mellitus). The outcome of the study showed ample evidence in regard to the action of the drug. The drug was prepared using fresh ingredients. Ayurvedic pharmacology depends on five principles of Rasa (essence)- Guna(quality),Virya (potency)- Vipaka (post-digestive effect) and Prabhava (special effect). ${ }^{12}$ Acharya Charaka has mentioned that any dravya (drugs) can have similar Rasa (essence)- Guna- (quality),Virya (potency)- Vipaka (post-digestive effect) but a different mode of action which can be explained on the basis of prabhava. ${ }^{13} 50 \%$ patients belonged to age group 41-50 yrs. 60\% were Males and $40 \%$ females. 53.34\% of total cases were having Kaphapitta prakriti. Majority of cases were having Madhyama Samhanana (medium) (66.67\%) and Madhyama Satva(60\%).Majority of patients were presenting Prabhuta Mutrata(polyurea) (100\%) as chief complaint. Trishnadhikya \& Gala-talu-shosha were also found in $100 \%$ patients. Avila mutrata was observed in $33.33 \%$ of the cases. Among Main Signs and Symptoms, highly significant relief $(\mathrm{P}<0.001)$ was obtained in Prabhuta mutrata (71.50\%) and Trishnadhikya \& Galatalu- shosha (57.72\%). Effect on Avila mutrata (Turbid urine) was statistically insignificant.6.66\% patients obtained control over diseased condition $16.66 \%$ patients provided Marked Improvement, Moderate Improvement was observed in $40 \%$ of cases, $36.66 \%$ cases showed Mild Improvement in Signs and Symptoms. Total improvement in Fasting Blood Sugar was $26.11 \%$ and that of in Postprandial sugar was $20.91 \%$ which are statistically highly significant. Among them, $23.33 \%$ patients obtained Control in F.B.S. value and $10 \%$ in P.P.B.S. value. Marked Improvement in F.B.S. was seen in $33.34 \%$ cases and $20 \%$ in P.P.B.S. Moderate Improvement in F.B.S. and P.P.B.S. was seen in $30 \%$ cases. P.P.B.S. of $6.67 \%$ patients remained unchanged. Not any adverse effects of Brhutayadi yoga were reported in this study.

\section{PROBABLE MODE OF ACTION :}

As far as mode of action is concerned, Ayurvedic view has already been discussed in Drug Contrive. According to modern medical science, the mechanism of action of the drug may be one of these:

1. By decreasing absorption of glucose from the gut.

2. By increasing peripheral utilization of glucose.

3. By stimulating Beta cells to produce more insulin.

4. By increasing insulin sensitivity.

\section{CONCLUSION}

Present study was conducted with limited time, limited facilities and limited number of patients. A study of larger group of patients may help to comprehend the mode of action of the Study drug has capacity to improve signs-symptoms and biochemical parameters.

\section{Acknowledgement-None \\ Conflict of interest-None \\ Financial Support-None}

\section{REFERENCE}

1. https://www.ncbi.nlm.nih.gov/pmc/articles/PM C5198827/,downloadedon 12/01/2021.

2. https://www.researchgate.net/publication/3419 77856_AN_OUTLOOK_OF_DIABETES_ME LLITUS_IN_CONTEXT_OF_PRAMEHA_R OGA_IN_AYURVEDA , downloaded on $5 / 02 / 2021$.

3. https://www.sciencedirect.com/topics/engineeri ng/diabetes-mellitus\#, downloaded on 6/02/2021.

4. https://www.ncbi.nlm.nih.gov/pmc/articles/PM C3068646/, downloaded on 6/02/2021.

5. https://www.ncbi.nlm.nih.gov/pmc/articles/PM C5426415/, downloaded on 10/02/2021.

6. Brahmashankar Shastri Yogaratnakara: Vidyotini Tika, Chaukhambha Sanskrit Sansthana, 6th Edi. 1997.pp-786 
7. Narhari pandit: Raj Nighantu - With Dravyaguna Prakachika Vyakhya, I.D. Tripathi, Ed.1982.pp-876

8. Kashinath Shastri and Gorakha Nath, Charaka Samhita with Vidyotini Hindi, chapter 7 verse 45, Chaukhambha Bharati Academy Varanasi.1999pp-564

9. Dr. Anil Bhadoria, Dr. Sakshi Gupta, A clinical Study on Role of Gramya Ahara

(Dietetics \& Life Style) in aetiopathogenesis of Prameha (Type 2 Diabetes Mellitus) and evaluation of hypoglycaemic effect of Bhudhatryadi yoga, IRJAY, December :
2020 Vol- 3, Issue-12; 1-15;

10. https://www.ncbi.nlm.nih.gov/pmc/articles/PM C2687091/, downloaded on 17/ 02/2021.

11. https://apps.who.int/iris/bitstream/handle/1066 5/42609/9241590416.pdf; sequence $=1$ downloaded on 17/ 02/2021.

12. https://www.ncbi.nlm.nih.gov/pmc/articles/PM C3068646/, downloaded on 20/ 02/2021.

13. Kashinath Shastri and Gorakha Nath, Charaka Samhita with Vidyotini Hindi, chapter 7 verse 45, Chaukhambha Bharati Academy Varanasi.1999pp-564 